\title{
Civic Education and Student Responses to Global Issue
}

\author{
Surya Dharma, Sapriya, Udin S Winataputra, Kokom Komalasari \\ Civic Education Department \\ Universitas Pendidikan Indonesia \\ Bandung, Indonesia \\ dharma0303@yahoo.co.id, k.sapriya@gmail.com
}

\begin{abstract}
This study is based on thinking that Civic Education has role in building students' global insight and awareness. Through Civic Education, students will aware of their role and responsibility toward global issue. One of the most effective ways to improve the world and help people inside it is through social movement. Therefore, Civic Education has role to encourage students in understanding complex global issue and deciding what step and action done as the form of response to global challenge. This study aims to reveal how the role of Civic Education course in State University of Medan in building students' global insight and awareness, and how students view on the importance of social movement in responding global issue. The approach used in this study is qualitative and quantitative, with naturalistic method and descriptive analysis through survey. The study result showed that (1) Civic Education Course in State University of Medan had not optimized the effort to develop students' global insight and awareness. (2) Students have good view of global issue, but it is not showed through action and social movement in solving that global issue.
\end{abstract}

Keywords—civic education; global issues

\section{INTRODUCTION}

Globalization is marked by the increase of various social movements struggling for humanity values. It shows that citizens have had collective awareness for better life in the world. The social movement which stand firmly on moral identity has encouraged everybody to help anyone even though they are not from their group even their nation. Regardless where we come from and what our economic status, if one problem concerning humans life survival and the world in the future, then it needs the uniformity in thinking and action to solve that problem. It is called global mindset which view the planet as organic entity, in which all parts are interconnected and interdependent [1]. This global mindset or global insight can be build through Civic Education in both school and community. Civic Education help students (university students) to more familiar with various global issues. Therefore, it encourage them to be actively involved in responding those issues through social movement. This aim called as Global Civic Education.

In some countries, Global Civic Education become a trend even necessity [2]. It is done to strengthened students existence as part of global citizen [2]. Students obtain much benefits from learning social justice issues, particularly which related to gender, carbon emission and global impact [3]. The implication of this study needs framework to develop the continuity of curriculum in the future. One education curriculum which needs to reinforce global insight and awareness is Civic Education. The importance of reforming Civic Education so it reflect culture reinforcement and diverse groups [4]. Banks [4] also assert that through effective and transformative Civic Environment, it will help students to acquire knowledge, skill and values needed in their cultural community, state and nation and global community. Furthermore, Banks [4] assert that such an education can help students to acquire cosmopolitan perspective and values needed to strengthened social justice and equality in the whole world.

Some result of studies above assert the importance of education which can strengthened students role as part of global citizen. That role can be build through Civic Education. Therefore, this study will examine empirically how Civic Education in State University of Medan build students' global insight and awareness, and to see how student responses to various global issues and social movements.

Building students' global insight and awareness is important because today there are so many problems derived from various global issues. The global warming occurred as a result of environmental crisis, conflict ended in human right violation, poverty and global gap, terrorism, world food crisis, infectious disease such as aids and avian influenza, narcotic and drugs, nuclear weapon proliferation are some global issues which get world attention and impacted on local life. Therefore, Civic Education is considered as learning program which play big role in accommodating globalization development and strengthening students role to be involved in broader social life. Through Civic Education, students are taught to live more tolerant, has empathy and affection to everyone. Because basically Civic Education aims to produce democratic citizens, that is, citizens who are intelligent and utilize their intelligence to develop themselves and their environment [5]. One intelligence expected is the ability to understand their role as part of world (global) citizens. This article will discuss how the implementation of Civic Education learning which is done now in State University of Medan in building students' global insight and awareness, and how its 
effect on students view on global issue through social movement.

\section{THEORETICAL FRAMEWORK}

\section{A. Civic Education and Global Citizenship}

In international perspective, the development of democracy education cannot be separated from the tendency of globalization and democratization movement which is increasingly globalized [6]. This tendency open the access for citizens to do democracy process and to develop human rights in all life aspects. Globalization capable to open thinking and action horizon of citizens wherever they are. This is the role of education to accommodate all tendencies from globalization process. Education program should capable to build global citizens who are able to manage the crisis [6]. In relating to it, there is a need to develop multidimensional civic competence through Civic Education Course in Higher Education.

Civic Education is one compulsory course in Higher Education in Indonesia. As compulsory course, Civic Education has mission to develop civic competence in the form of knowledge, attitude and skill in order to produce intelligent graduates and possess nationalism spirit and love motherland based on Pancasila values. Of course it's not easy to achieve that goal. Civic Education should be transformed to become learning program which not only function as subject in class, but it is comprehensive in both content and management. The development of knowledge, skill and attitude not only limited to what is mentioned in curriculum. Civic Education should always interact with the development of thinking on democracy education and development of local, national and global community [6].

Civic Education should be able to suit with the condition of contextual life in local, national and global nuance. Because life dynamic in the world today demand students to know their role as part of community not only in local and national level, but also in global level. This role and responsibility should be cultivated in order to maintain human life welfare. In facing global challenge, students are expected to possess some competences which can enhance their role as global community. This global competence should be supported by global learning process through global citizenship education.

Global citizenship education focus on shaping students' disposition in order to have awareness as global citizen. The goal is to prepare young generation in facing opportunity and challenge as part of global community. Therefore, there is a need to transform Civic Education in education of $21^{\text {st }}$ century [7]. The importance of global citizenship education basically form strong moral commitment for global humanity. Strengthening humanity value in universal care is the main key of global citizenship. This attitude will generate students who have global perspective and grow global responsibility as part of global citizenship competence.

\section{B. Global Issue and Citizen Social Movement}

Globalization can be mentioned as one factor which force various global issues. Free trading, environmental crisis, poverty, migration, threat of infectious disease are among world problems caused by the life which is increasingly globalized. Why globalization is mentioned as one forcing factor. Citing the opinion of Cohen and Kennedy [8] identify six globalization components, namely:

(1) changing concepts of time and space; (2) an increasing volume of culture interactions; (3) the commonality of problems facing all the world's inhabitants; (3) growing interconnections and interdependencies; (4) a network of increasing powerful transnational actors and organization; (5) the synchronization of all the dimensions involved in globalization.

Those six globalization components above show that globalization is characterized by problems which are increasingly interconnected and interrelated among each other, not limited by country and arouse various social movements to respond those issues. Cohen and Kennedy [8] concluded that globalization bring the real world to 5 billion people as object of attention, in which each person has collective interest and do collective action to solve global problems. It shows that on one side, globalization influence humans life that cause various global problems, but on the other side, globalization can be mentioned as factor which influence citizen to be involved in responding that problem.

Next the author examine how citizen attitude to various global issues. Why citizen should care about that issue. In addition, how citizen respond various global problems. This thesis is not something new because the world today is interconnected and interdependent. This thesis indicate that global issue is a necessity and has logical consequence for citizen life. Because this issue is global so its impact also felt globally, not only in the other side of the world, but where each citizen live [9]. In overcoming it, the collective action by all people is needed through social movement. The world we live now has two opposite dynamics namely economic globalization and approach to social change based on collective interest, which cause broader social movement [10]. It proves that social movement is the most effective to solve various global issues. Because social movement can be made to become democratic vehicle from trans national group representative [8]. Citizen social movement is political democracy practice to influence government policy to social change. Social movement only possible to be done by broadening the strength basis of interest group, and social movement is political vehicle of concerned interest group [10].

\section{METHODOLOGY}

This study use qualitative and quantitative approach by using mix method as research design. Qualitative approach use naturalistic method, whereas quantitative approach use descriptive analysis method through survey approach. Sample in this study are 6 lecturers who teach Civic Education course in State University of Medan and 138 students who take Civic Education course. Sampling done by using purposive random sampling. Because this study use mix method, design study used are: (1) conduct in-depth interview with Civic Education lecturers to find out how the role of Civic Education in State University of Medan in building students' global insight and awareness; (2) conduct interview with students to find out their 
view of global issues and social movement in responding those issues; and (3) distribute questionnaire to find out how their view of various global issues; and (4) conduct document analysis of teaching material, learning source and learning tool used by lecturers in Civic Education learning so far. Qualitative data analysis is done in structure and in depth, whereas quantitative data analysis is done by using percentage to see students' response and view on various global issues.

\section{STUdy RESUlT AND DisCUSSION}

\section{A. Study Result}

1) Civic education in State University of Medan in developing students' Global Insight and Awareness: To identify whether Civic Education learning in State University of Medan had accommodated the development of students' global insight and responsibility, the researcher examine (1) learning plan; (2) learning process; (3) teaching material and learning resource, and (4) lecturers view on the role of Civic Education in building students' global insight and awareness. The following is the result of study.

To find out whether Civic Education learning plan which had been developed now had accommodated students' global insight and responsibility, the researcher conducted the analysis of learning tool document such as Syllabus, Learning Plan for Semester which had been developed by lecturer. Analysis of learning tool documentation is done to see whether Learning Achievement, competence and indicator, material, learning steps, and evaluation had accommodated the development of global insight and responsibility among students.

The analysis result of learning tool document which had been developed by Civic Education lecturer showed that: (1) Syllabus and Learning Plan for Semester had not been accommodated the development of students' global insight and responsibility. It is seen from the formulation of Learning Achievement, the formulation of competence and indicator, material, learning steps, and evaluation which in general had not included study about students' role as part of global citizens. (2) Syllabus and Learning Plan for Semester which had been developed is very tied to the existing curriculum. The lecturer less explore the study beyond the material contained in it. It is in accord with the result of interview with a lecturer who say that:

"It's true, sir. Each lecturer should has learning tool in the form of Syllabus, Learning Plan for Semester, and study contract. The development of syllabus and Learning Plan for Semester is done by paying attention to Civic Education materials contained in teaching material and the provision which had been set in The Decree of Directorate General of Higher Education, National Education Department of Republic of Indonesia No.43/DIKTI/Kep/2006 about the rules for implementing the group of personality department course. It is added by rule reinforcement in Indonesian National Qualification curriculum. If it is seen from a whole, the developed Civic Education learning tool had not accommodated students' global insight and responsibility." (Lecturer FR)
To clarify what had been expressed by the respondent above, the researcher conduct the analysis of learning tool document which had been developed by The Team of Civic Education Lecturers in State University of Medan. The learning tool document analyzed are Syllabus, Learning Plan for Semester, and Course Contract. From the analysis result, it is seen that learning tool developed by Civic Education lectures in State University of Medan had not in written included the study about development of global insight and awareness among students.

Similarly with Teaching Material used by Civic Education lecturers in State University of Medan. The development of teaching material is done by referring to The Decree of Directorate General of Higher Education, National Education Department of Republic of Indonesia No.43/DIKTI/Kep/2006 about the rules for implementing the group of personality development course. What are studied in the book developed by Civic Education lecturers in State University of Medan are:

(1) Civic Education; (2) Philosophy of Pancasila; (3) Pancasila as Ideology of a Nation; (4) National Identity; (5) Indonesia Democracy; (6) State and Constitution; (7) Rule of Law and Human Rights; (8) Geopolitic, and (9) Indonesian Geostrategy (Civic Education Teaching Material, State University of Medan, Year of 2017).

From analysis of teaching textbook developed by The Team of Civic Education Lecturers in State University of Medan, the researcher saw that there is no study or material specially related to development of students' global insight and awareness. Teaching material is still general and not related to students' role as part of global citizens. The teaching textbook developed is more dominant on development of citizen's knowledge aspect and had not accommodated development of attitude and skill competence as part of local, national and global citizen.

In addition, of textbook as learning resource, the lecturers also use another learning resources such as journal, newspaper, and various relevant information taken from internet. In the effort to develop students' global insight and awareness, some lecturers also usually use various learning resources related to contemporary global issues such as environment, terrorism, interethnic conflict, etc. It is as said by a lecturer that:

"Usually I always stimulate students with the topics related to contemporary global issues. Those topics certainly related to interdependency among countries in global era", (Lecturer PRY)

The result of interview above shows that some lectures of Civic Education in State University of Medan try to relate the material to the topics which are related to development of students' global insight, through various learning resources. However, it is believed that learning process still in the form of knowledge development (cognitive), and it had not reinforced citizen's attitude and skill in solving various global issues. It is as said by a lecturer that:

"I believe that Civic Education learning which is implemented now still reinforce student knowledge (cognitive), and less give attention to development of attitude and skill as the goal of Civic Education. Similarly 
with development of student's global awareness. " (Lecturer $H D)$.

Another lecture expressed the similar opinion that:

"In general Civic Education learning had been done well, but it's true that development of students' global awareness had not been done maximally. If it is delivered, it is only related to reinforcement of students' global insight by relating Civic Education material to various global issues such as environment issue, humanity issue, global warming, etc." (Lecturer AG)

From the interview above, it can be understood that Civic Education learning in State University of Medan had not reinforced students' global awareness and responsibility. The Minister of Education and Culture say that Civic Education only delivered to reinforce students' global knowledge (insight), and it had not developed students' attitude and skill aspect. Learning which is still conservative is though as one reason why Civic Education in State University of Medan had not been able to develop global skill and attitude among students. It is as said by a Lecturer that:

"Civic Education learning often use lectures and questionanswer methods. These two methods are very suitable to be used in delivering Civic Education materials which are fact, concept and principle in nature. So, these methods are very appropriate to be used in Civic Education learning." (Lecturer HD)

The result of interview above shows that the use of conventional method in learning, become one factor which cause Civic Education is lack in exploring students' global responsibility. Whereas in the other side, Civic Education lectures in State University of Medan said that development of students' global awareness and responsibility is needed. It is seen from what had been said by a lecturer that:

"In the life which is increasingly globalized like today, Civic Education in Indonesia is demanded to suit with global tendency. One of them is by reinforcing global responsibility toward global issue occurred. And that attitude needs to be exist in each student." (Lecturer FR)

Based on what had been said by the Lecturer (FR) above, it can be understood generally that the Civic Education lecturers in State University of Medan support learning which build students' global responsibility. The globalized life and interdependency among one another are the reasons why we need to reinforce global responsibility in students. However, it can be realized that development of global responsibility in students cannot be implemented maximally. It is as said by a lecturer that:

“Civic Education today had not developed students' global responsibility, if we compare it to citizenship concept developed by another country such as US or Finland, for example. Civic Education in Indonesia is too values inculcation. And as if that it is still trapped in dogma, moral and knowledge dimensions only." (Lecturer SH)

From the result of interview above, it can be understood that in general Civic Education lectures in State University of Medan agree that Civic Education has role and responsibility to build students' global insight and awareness. However, the learning process of Civic Education had not been able to develop students' global insight and awareness. The rigid learning plan which is tied to curriculum and learning process which is conservative is one factor which cause Civic Education in State University of Medan had not maximally developed students' global insight and responsibility. It is also influenced by teaching material, learning resource and media which are very tied to the existing curriculum.

The learning process of Civic Education which is lack in accommodating the development of students' global insight and awareness certainly will influence students' perception, knowledge, attitude and skill in responding global issue. Because basically, students as civil society need to develop with more global way, by strengthening self-awareness as citizen and how they can act collectively as global citizens [8]. Therefore, the role of Civic Education is very needed in building students' global insight and awareness.

2) The response of students in State University of Medan to global issue through social movement: Before identifying students' social movement in State University of Medan in responding global issues, the researcher explained first how students view the importance of social movement. The researcher distributed questionnaire to 138 students in 5 study programs/department in State University of Medan. Those study programs are Accountant Education, Pancasila and Civic Education, Office Administration, Make Up Engineering, Sport Training Education, and Building Engineering. The study result is explained in the table below.

TABLE I. PERCENTAGE OF STUdents' VIEW About SOCIAL MOVEMENT IN RESPONDING GLOBAL ISSUES

\begin{tabular}{|l|l|l|l|}
\hline \multirow{2}{*}{ No } & \multicolumn{1}{|c|}{ Statement } & \multicolumn{1}{|c|}{$\begin{array}{c}\text { Number of the } \\
\text { percentage (\%) }\end{array}$} \\
\cline { 3 - 4 } & \multicolumn{1}{|c|}{$\begin{array}{c}\text { VS\&A } \\
\text { If being asked, I am willing to become } \\
\text { volunteer to help solving various } \\
\text { problems which become world human } \\
\text { issue. }\end{array}$} & 58.69 & 18.84 \\
\hline 2 & $\begin{array}{l}\text { If being asked, I am ready to do action } \\
\text { (demonstration, campaign, seminar, etc) } \\
\text { in supporting the resolution of world } \\
\text { global issues. }\end{array}$ & 43.47 & 30.43 \\
\hline 3 & $\begin{array}{l}\text { If given a change, I am ready to join } \\
\text { various human institutions both national } \\
\text { and global, to give contribution to realize } \\
\text { better world civilization. }\end{array}$ & 56.52 & 21.73 \\
\hline 4 & $\begin{array}{l}\text { I am comfort to express my opinion or } \\
\text { my view about global issue in front of } \\
\text { people. }\end{array}$ & 45.37 & 29.63 \\
\hline 5 & $\begin{array}{l}\text { If given a change, I will write in } \\
\text { newspaper or in blog, web, etc, to express } \\
\text { my concern about global environment, } \\
\text { social and political problem. }\end{array}$ & 53.33 & 20.74 \\
\hline 6 & $\begin{array}{l}\text { I am willing to help and participate in } \\
\text { various global issue only if it is assigned } \\
\text { by lecturer or campus. }\end{array}$ & 59.42 & 24.46 \\
\hline
\end{tabular}

Note: $\mathrm{VA}=$ very agree, $\mathrm{A}=$ agree, $\mathrm{D}=$ disagree, $\mathrm{VD}=$ very disagree

The percentage result of data in the table above shows that in a whole, students in State University of Medan have positive view toward social movement in responding global issues such 
as they are willing to become volunteer to help various humanity issue problem in the world (58.69\%). They are ready to join various humanity institutions both national and global $(56.52 \%)$. They are comfort to express their views about global issue in front of people $(45.7 \%)$ and will write in newspaper or blog, web, etc. to express the anxiety about various global problems $(53.33 \%)$. This percentage result describe that basically students understand to solve various global issues. Active involvement is very needed both individually or group such as join various humanity institution, responding global issue in written form in newspaper, blog, social media and web and cooperate with others even though beyond cultural bond.

The table above also shows that $43.47 \%$ of students agree to respond global issue through social movement (campaign, demonstration and seminar) and $30.43 \%$ of students do not respond global issue through social movement (campaign, demonstration and seminar). From this data, it is seen that there are still some students who are doubt even do not want to do various social movement actions in responding global issue. It means that there is no awareness in students to participate in responding global issue. This data is corroborated by result of interview with students which ask their perception on global issue, and what they had done in responding that issue. The following is the result of the interview with 10 students in State University of Medan.

"Global issues are not good so people should be careful in responding those issues. In responding various global issues, for now there's nothing I do”. (Student RV).

"I feel sorry knowing those global issues, because people will get the impact from those issues". In responding the issues, I usually pray that all disasters will end". (Student $\mathrm{DH})$.

"The response I get about those issues is feeling upset and sad. Even there is no solution to those issues, so there is no change at all. There is no action I do in responding those issues". (Student NA).

"Students should be more respond and more care about global issues. My response to those global issues is giving contribution to organizations which channel that contribution". (Student NAS).

From the result of interview above, it is seen that some students show stereotype attitude to global issue by responding that issue as a threat for everybody and it should be avoided. Whereas some students consider that global, issue is collective issue and become responsibility of everyone. Therefore, the empathy attitude to global issue is needed. There are various kinds of empathy done by students in responding global issue such as doing pray, giving help/contribution, planting mangrove, etc. These efforts are done as form of responsibility in responding various issues happened. However, it can be known that in responding global issue, most students are still influenced by initiation from campus, organization, LSM, government, etc.

It is corroborated by percentage result which state that students will participate in various global issues if they are only assigned by lecturer or campus (59.42\%). This data also corroborated by result of interview with students who do action in responding global issue initiated by campus or students organization such as:

Planting mangrove which is done by Pancasila and Civic Education Department, Geography Department and another study programs as the form of care toward environmental issue,

Doing peace action, pray together, and collect the aid for Ronghinya ethnic in Myanmar, Palestine, and another place initiated by internal and external organization in campus such as Indonesian Muslim Students Action Unity, Indonesian Students Association, and another student organization; and

Various forms of participation in responding global issues. (Processed from various sources done through interview and observation).

From the study result, it can be concluded that students aware the importance of responding various global issues. Because global issue will influence the survival of humans life both in present time and in the future. Therefore, it needs the effort to build students' global insight, awareness and responsibility. However, in fact, students in State University of Medan had not got learning which reinforce their global insight, awareness and responsibility. Therefore, the willingness to respond global issues not come from themselves. Therefore, it can be concluded that students who join one institution or organization have higher social opportunity in responding global issues compared to students who do not join institution or organization. Various social movements are initiated by certain institution or organization. It should be that each student has same awareness, responsibility and opportunity to do various social movements as response to various social movements. The effort to build global insight, awareness and responsibility needs to be cultivated through Civic Education course in Higher Education.

\section{B. Discussion}

In the life which is increasingly complex, citizen competence should be strengthened in order to be able to compete and contribute in community life whether local, national and global. Therefore, Civic Education not only teach students to know what it is means to become citizen, but how to apply their knowledge responsibly in political community [11], including in community as global citizen. One of knowledge which should be developed is ability to recognize and approach the problem as global community and capable to cooperate with others and responsible for their role and duty in community [12]. This competence is needed in facing various global issues threatening the life in this world both in the present time and in the future.

Therefore, Higher Education in pedagogic context should be able to increase understanding of all students on how citizenship problems by giving understanding and facilitating active, effective and meaningful processing [13]. Higher education should be in the front line to lead transition toward the safe and continuous future [14]. One main task of Higher 
Education is to build global insight and awareness in students through Civic Education Course.

The study result above shows that Civic Education learning which is implemented in State University of Medan up to now had not able to accommodate the development of students' global insight, awareness and responsibility. It influences student's participation in responding various global issues through social movement. The development of learning plan which is tied to curriculum, conservative learning process and teaching material, learning resource and learning evaluation which are less varied and innovative are some reasons why Civic Education course in State University of Medan less accommodate the development of global insight, awareness and responsibility in students. For macro context, this problem is not detached from condition of Civic Education in Indonesia, namely:

(1) There is inconsistency in curriculum and learning system, as a result of influence of change in politic life. (2) tend to favor formal-curricular demand in school and less pay attention to development of Civic Education as science discipline field; (3) tend to change its role and function become indoctrination process and inconsistency in outlining various goals of Civic Education in curriculum, and (4) the fragile of scientific base of Civic Education as democracy education program [15].

Various problems above hinder the implementation of Civic Education learning which is suited with globalization vision. Whereas in this global era, Civic Education learning should not only touch civic knowledge aspect. Civic Education should be designed as learning process to grow student's insight and care in facing broader social reality. The Civic Education learning outcome cannot be measured from formal learning process (in classroom) but as the effort to build students' thinking capacity to interact, doing dialog in social context (community) [13].

The broader citizen participation will form civic competence, attitude and skill such as civic knowledge, civic value, civic motivation, civic identity and civic action. This competence can be achieved if Civic Education learning in Higher Education capable to provide learning experience to students and it is not tied by formal curriculum. Because basically, school (Higher Education) is "mini government" and public space in which young people learn about how to learn and train skill needed for life in democratic community [16].

Some countries which characterized by students who are highly involved in responding global issue called as "maximal" citizenship. McLaughin [17] explain that "maximal" citizenship view that citizen have awareness as members of society who live together with democratic culture and involve responsibility, right and duty. Meanwhile in "minimal" view according to [17] citizenship identity inherent in individual only seen in formal, law or judicial requirement. This view is more characterized as conventional citizenship in which citizens participate through formal procedure of democracy [17].

In dynamical life like today, citizen should be more mobilized in responding citizenship issue (including global issue). This characteristic called as social citizenship [17], in which social movement in responding to global issue is done through active participation in society life. Reinforcement is done systematically through Civic Education as the effort to broaden democratic participation among citizens. In this context, Cogan [5] recommend that education in the future based on conception of multidimensional citizenship as consequence which is suited with human desire in $21^{\text {st }}$ century.

Civic education not only educate students to have global insight, without accompanied by active participation in solving global problem. It is characteristic of civic competence in $21^{\text {st }}$ century, namely ability to see and approach problem as member of global community [12]. Therefore, Civic Education as democracy education should be able to emphasize the importance of citizen role to face tendency in handling various global problem. Through Civic Education, students are encouraged to understand the complexity of global problem, and decide what steps or actions should be done as citizen responses to global challenge [12]. Because global challenge cannot be delegated to the others, so it needs personal responsibility from everyone to maintain global welfare by concerning right and duty of the others [12]. Therefore, the role of Civic Education is very needed in building citizen awareness and active participation to create better life in the world. It is the characteristic of citizenship in $21^{\text {st }}$ century which seeing ourselves as world actor, responsible in fighting injustice to maintain continuity [12]. This characteristic is in accord with the vision of Global Citizenship Education to involve people in order to be interconnected to handle social injustice such as poverty. Famine, inequality, and human oppression and alienation [18]. Because the main concepts which base global Civic Education are justice, diversity, identity and ownership, and sustainability development, in which in all places there is emphasis on centrality of diversity [18].

The main concept of global Civic Education not only taught to students, but it should be developed through active participation to be involved in solving various global problems. So later, students will get benefit from school which give opportunity to apply active participation skill before they are adult [16]. Building active citizenship needs formative approach, moral autonomy, critical thinking, meaningful, relevant, combine daily life as knowledge source to give meaning to law, value and procedure relate to conflict resolution [19].

In relating to that, there is a need to construct the role of Civic Education as course which not only strengthened civic knowledge, but also building active participation and awareness in solving various social problems, including global problem. The study result above showed that students have good view of global issues. However, it is not showed through action or social movement in solving that global problem. Whereas social movement is admitted as important aspect in politic life, and describe brightness in democracy implementation in a country.

Social movement is the effort to transform value and norm in citizenship practice through citizen active involvement in facing various social problems in local, national and global context. Building social movement is the effort to increase 
citizen understanding about various citizenship problems through interaction, dialog, negotiation, consensus, reflection, cooperation through citizen involvement which is active and responsible. Building active citizen needs understanding about concept and principle, skill to reflective action and being responsible, willingness to be involved and commitment in democracy values [13]. This effort can be done through Civic Education as learning program which support development of attitude, knowledge and skill as multidimensional citizenship competence in global era.

\section{CONCLUSION}

Basically, everyone has moral responsibility to create better life in the world by upholding human values, justice, diversity and sustainability development. The effort to build this moral responsibility can be developed through Civic Education. This paper give a conclusion that there is interrelated relation between Civic Education to reinforce students' insight, awareness and responsibility in responding global issue. Because basically Civic Education is learning program which encourage students to have some competences such as knowledge, attitude and skill.

In the global era, students need to be equipped by civic competence in order to be able to see various challenges for self-reinforcement and nation identity. One national identity of Indonesian nation is upholding humanity and justice values. This national identity is part of Pancasila value as Indonesian Nation Ideology. The values in this Pancasila Ideology is universal because every nations in the world can accept it. Therefore, the care attitude toward environment, people or another nation needs to be developed in students as the effort to implementing the values in Pancasila ideology. The care attitude toward environment, people or another nation is characteristic of global citizen which should be developed through Civic Education. Therefore, Civic Education not only develop civic knowledge, but also help students acquire new experience to be actively involved in responding global issue. This study corroborate that goal, that is, how Civic Education capable to give understanding, skill and values needed by students to cooperate in solving interrelated challenges in $21^{\text {st }}$ Century [20]. Particularly the ability to respond various global issue as the effort to create better life in the world.

\section{ACKNOWLEDGEMENT}

The researcher would like to thank to Ministry of Research, Technology and Higher Education who had financed part of this study and students and lecturers of Civic Education in State University of Medan who are willing to become respondents in this study.

\section{REFERENCES}

[1] Chandra, D., From Corporate Citizenship to Global Citizenship. In Derickson et all (Eds). Awakening Social Responsibility a Call to Action. Rosella Derickson At All. Callifornia USA: Silicon Valley. pp $27-33,2007$
[2] Dill, J. S., The Moral Education of Global Citizenship'. Journal Global Sociaty. Soc. (2012) 49: pp 541-546. 2012.

[3] Boetto, H., and Bell, K., 'Environmental sustainability in social work education: An online initiative to encourage global citizenship', International Social Work Vol. 58 (3) pp 448-462, 2015.

[4] Banks, J. A., 'Diversity,Group Identity, and Citizenship Education in a Global Age' Educational Researcher, Vol. 37, No. 3, pp. 129-139. 2008.

[5] Wahab, A., and Sapriya, Teori dan Landasan Pendidikan Kewarganegaraan. Bandung: Alfabeta. 2011.

[6] Winataputra, U. S., Budimansyah, D., Civic Education: Konteks, Landasan, Bahan Ajar dan Kultur Kelas. Bandung: Program Studi Pendidikan Kewarganegaraan SPS UPI. 2007.

[7] Munck, R., Civic Engagement and Globa Citizenship in a University Context : Core business or desirable add-on?, Arts \& Humanities in Higher Education. vol 9(1) 31-41, 2010.

[8] Mayo, M., Global Citizens: Sosial Movements and the challenge of globalization. London-New York: Zed Books. 2005.

[9] Bhargava, V., Global Issues For Global Citizen: An Introduction to key Development Challenges. Washington DC: The World Bank. 2006.

[10] McIntyre-Milss J. J., Global Citizenship and Social Movements: Creating Transcultural Wbs of Meaning for The New Millenium. Taylor \& Francis: Routledg's collection. 2005.

[11] Peterson, A., Civic Republicanism And Civic Education. Palgrave Mcmillan. 2011.

[12] Budimansyah D, and Suryadi, D., PKn dan Masyarakat Multikultural. Bandung: Program Studi Pendidikan Kewarganegaraan SPS UPI. 2008.

[13] Haste, H., Bermudez, A., Carretero, M., Culture and Civic Competence: Widening the Scope of the Civic Domain. In Garcia, et all (Eds). Moral Development And Citizenship Education: Civic and Citizenhsip: Theoritical Models and Experiences in Latin America. Rotterdam/Boston/Taipe: Sense Publishers. 2017.

[14] Shiel, C and Jones D., Sustainbility and Social Justices: Leadership Chalenges. In Lynette Shultz and Melody Viczko (Eds). Assembling and Governing the Higher Education Institution: Democracy, social justice and leader ship in global higher education: Palgrave Macmillan. pp $11-$ 34. 2016.

[15] Winataputra, Jati Diri Pendidikan Kewarganegaraan Sebagai Wahana Sistemik Pendidikan Demokrasi (Suatu Kajian Konseptual dalam Konteks Pendidikan IPS). Ringkasan Disertasi. Program Pascasarja UPI. 2001.

[16] Kwok J., Selman., RL. From Informed Social Reflection to Civic Engagement: How to Interpret What Youth Say and Do. In Garcia, et al (Eds). Moral Development And Citizenship Education: Civic and Citizenhsip: Theoritical Models and Experiences in Latin America. Rotterdam/Boston/Taipe: Sense Publishers.pp 17-38. 2017.

[17] McCowan T., Rethinking Citizenship Education: A Curriculum for Participatroy Democracy. London: Continuum International Publishing Group. 2009.

[18] Davies, I., The Palgrave Handbook of Global Citizenship and Education. London: Palgrave Macmillan, 2018.

[19] Conde, Civic And Ethical Education In Mexico: From Classic Civics to the Development of Civic and Citizenship Competence. In In Garcia, et all (Eds). Moral Development And Citizenship Education: Civic and Citizenhsip: Theoritical Models and Experiences in Latin America. Rotterdam/Boston/Taipe: Sense Publishers.pp 41-46, 2017.

[20] United Nations, United Nations Secretary-General's Global Education First Initiative. 2012. 